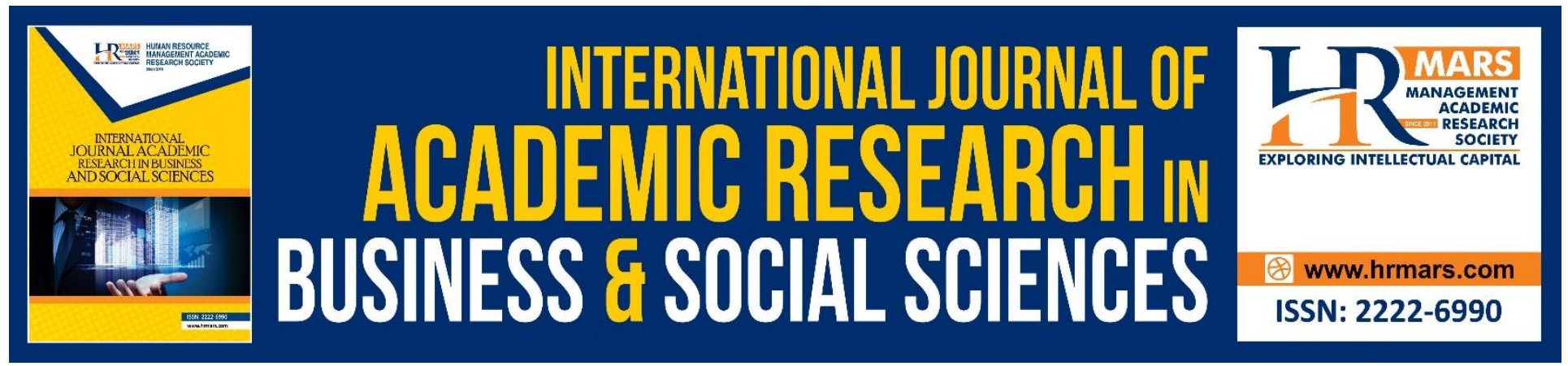

\title{
The Influence of Company's Reputation and Company's Financial Performance towards Tax Planning of Public Companies in Indonesia
}

Fajar Lina, Yossi Diantimala, Zuraida

To Link this Article: http://dx.doi.org/10.6007/IJARBSS/v8-i8/4469

DOI: $10.6007 /$ IJARBSS/v8-i8/4469

Received: 02 August 2018, Revised: 27 August 2018, Accepted: 30 August 2018

Published Online: 03 Sept 2018

In-Text Citation: (Lina, Diantimala, \& Zuraida, 2018)

To Cite this Article: Lina, F., Diantimala, Y., \& Zuraida. (2018). The Influence of Company's Reputation and Company's Financial Performance towards Tax Planning of Public Companies in Indonesia. International Journal of Academic Research in Business and Social Sciences, 8(8), 279-290.

Copyright: (c) 2018 The Author(s)

Published by Human Resource Management Academic Research Society (www.hrmars.com) This article is published under the Creative Commons Attribution (CC BY 4.0) license. Anyone may reproduce, distribute, translate and create derivative works of this article (for both commercial and non-commercial purposes), subject to full attribution to the original publication and authors. The full terms of this license may be seen at: http://creativecommons.org/licences/by/4.0/legalcode

Vol. 8, No. 8, August 2018, Pg. 279 - 290

Full Terms \& Conditions of access and use can be found at http://hrmars.com/index.php/pages/detail/publication-ethics 


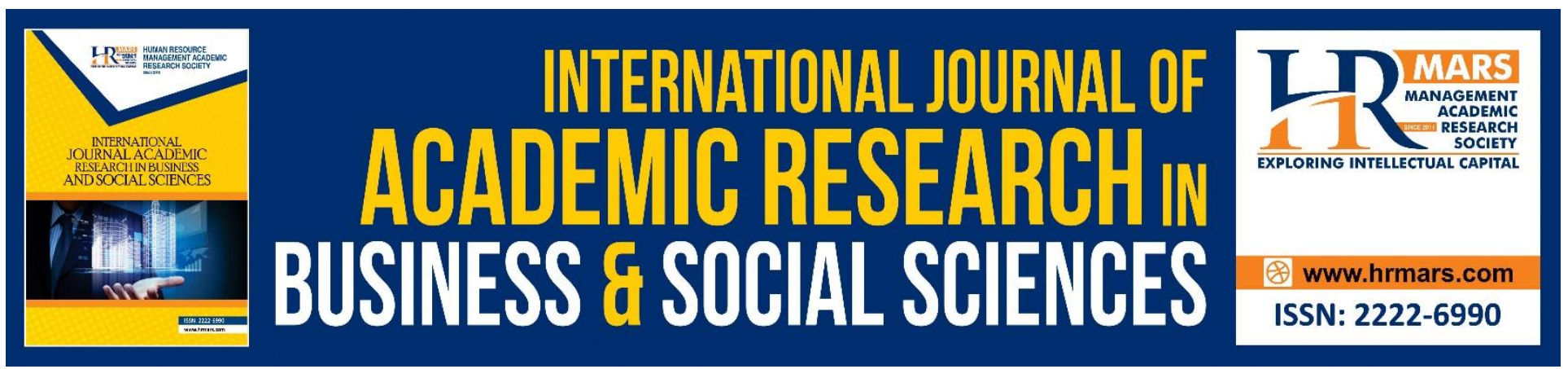

\title{
The Influence of Company's Reputation and Company's Financial Performance towards Tax Planning of Public Companies in Indonesia
}

\author{
Fajar Lina ${ }^{1}$, Yossi Diantimala², Zuraida ${ }^{3}$ \\ ${ }^{1}$ Student in Master of Accounting, Faculty of Economics and Business, Syiah Kuala University, \\ Banda Aceh, Aceh, Indonesia \\ ${ }^{2,3}$ Lecture in Master of Accounting, Faculty of Economics and Business, Syiah Kuala University, \\ Banda Aceh, Aceh, Indonesia
}

\begin{abstract}
The purpose of this research is to understand the effect of company's reputation and company's financial performance towards tax planning of public companies in Indonesia. The type of research is causality by using purposive sampling method and balanced panel data. The objects of research are 54 companies with 270 observation data during the period of 2012-2016. The type of data used in this research is secondary data in the form of Cll reports (Corporate Image Index) from Frontier Consulting Group Survey Institute, financial statements and annual report of the company. Hypothesis testing is done by using multiple linear regression analysis where data processing used SPSS (Statistical Product and Service Solution) version 24. The results of this research show that: (1) the company's reputation and company's financial performance simultaneously influence the tax planning; (2) the company's reputation negatively influence tax planning; (3) company's financial performance positively influence tax planning.
\end{abstract}

Keywords: Company's Reputation, Financial Performance, Tax Planning, ROE, GAAP ETR

\section{Introduction}

Taxes are the main source of income to finance the state expenditure, so that it demands the tax apparatus to work optimally to fulfill tax revenue targets. The government, in this case the Directorate General of Taxation has done various actions to improve the tax system in order to enhance compliance and convenience for WP (taxpayer) to pay tax by doing breakthrough tax reforms from the year of 1983 until 2020, so it is expected to grow WP trust to the government as tax funds manager, so that tax revenues increase to finance the development of the country.

According to the official data from the Directorate General of Taxation, as of 31 October 2016, non-oil and gas income tax revenue (non-PPh migas) amounted to IDR842.979 trillion consisted of total non-oil and gas income tax revenues of IDR513.266 trillion, Value Added Tax/VAT (PPN) and Sales Tax on Luxury Goods (PPN-BM) total revenue of IDR307.268 trillion, Land and Building Tax (PBB) revenue of IDR16.349 trillion and other tax revenues of IDR6.095 trillion. The amount of IDR842.979 
INTERNATIONAL JOURNAL OF ACADEMIC RESEARCH IN BUSINESS AND SOCIAL SCIENCES Vol. 8, No. 8, August 2018, E-ISSN: 2222-6990 @ 2018 HRMARS

trillion of non-oil and gas income tax revenue higher than the same period in 2015, which amounted to IDR724.988 trillion or about $16.28 \%$. Growth registered by non-oil and gas income tax is supported by the growth of other non-oil and gas income tax, Income Tax Article 22, Final Income Tax, Income Tax Article 23, Income Tax Article 25/29 for Body and Income Tax Article 26. Growth registered by Income Tax Article 25/29 for Body is IDR130.464 trillion compared to the same period in 2015, amounted to IDR125.449 trillion or about 4\%. However, beside growth, revenues in the non-oil and gas income tax sector also slightly decreased in the revenue of Income Tax Article 25/29 for person which decreased by amounted to IDR4.814 trillion compared to the same period in 2015 amounted to IDR5.110 trillion or about $5.79 \%$.

It cannot be denied, the decrease in Income Tax Article 25/29 for person revenue is maybe because WP doesn't understand how to calculate taxes or because taxes force WP to pay funds that are considered as a burden for WP, so that it has a tendency to reduce or avoid taxes. Indonesia implements a self-assessment system in which WP provides the authorization to calculate, pay and report its tax obligations. This allows to open the opportunity for WP to prepare financial statements by pressing the costs of the company to fit the amount of tax to be paid by doing tax planning action.

According to Suandy $(2003$, p. 3 ) the emphasis on tax planning is to minimize tax liabilities. Tax planning done by the company has 3 consequences to reduce the amount of tax which are (1) tax avoidance, where tax deduction is done legally by utilizing loopholes or weakness of tax regulations, (2) tax saving, where legal tax deduction actions are conducted by utilizing tax amount through the selection of alternatives according to tax regulations, and (3) tax evasion, where tax deductions are illegally conducted by violating tax regulations (Rahman, 2012). Tax planning is the activity to prepare WP financial in order to get minimum tax expense in which a WP attempt to gain tax saving through the stages of tax avoidance systematically in accordance with the Tax Law.

Tax planning actions undertaken by the company must be able to guarantee the prosperity of the company and also able to keep the company's reputation in public. Company's reputation is an intangible asset that describes the image and credibility of the company in the eyes of stakeholders. The quality of the company's reputation will determine the behavior of stakeholders towards the company, which will affect the achievement of company goals. The company's reputation is positioned as an important factor that limits tax planning activities, especially aggressive tax planning (Gallemore et al., 2014). Companies that conduct aggressive tax planning are perceived as poor companies, therefore impact the products of companies on the market. The article published in the New York Times criticized General Electric as one of the world's largest companies that didn't pay taxes to the US government in 2011. In response to these criticisms, General Electric stated that they didn't conduct tax avoidance that harmed the US government, but instead contribute greatly to the society, such as providing great employment, paying taxes on time, and its tax burden calculation is more broadly than salary, property, and sales tax. However, the society still commented "we will never buy this company's product again" (Graham et al., 2014). In Indonesia, there were also companies that conducted tax avoidance, one of the companies was PT. Coca Cola Indonesia, which increased its advertising expenses in 2002-2006 amounted to IDR566.84 billion, so that it created a shortage of tax payments of IDR49.24 billion. These events resulted in a decline in the company's reputation, sales and customer loyalty that impacted the company's financial performance.

The company's financial performance reflects the true company's health level (Christianti, 2014). Through financial statements, users of financial statements can understand the financial performance of a company and can predict the going concern of the company. Also, the company should be well managed the tax obligation so as not to be a serious disruption to the life of the 
INTERNATIONAL JOURNAL OF ACADEMIC RESEARCH IN BUSINESS AND SOCIAL SCIENCES

Vol. 8, No. 8, August 2018, E-ISSN: 2222-6990 @ 2018 HRMARS

company. For company, taxes are a burden that will decrease profits, where information about profits provides an overview of the financial performance and prospects of the company in the future that gives advantages for the users of financial statements.

The financial performance phenomenon proposed by Cook et. al (2017) which stated that with the highest marginal income tax rate at 35 percent, federal US taxes cause cash outflow of the companies to be so large that companies undertake tax avoidance activities to minimize their tax burden on income before tax and provide additional cash flow after tax for shareholders. Case example of PT. TMMIN (Toyota Motor Manufacturing Indonesia) undertake tax avoidance action in the form of transfer pricing, which is to move the burden of excess profits from one country to other country that implements lower rate of taxes (tax haven). The burden transfer is done by manipulating prices unfairly. Tax officers suspect that after 2003 TMMIN entered into unreasonable transaction related to royalty payments, purchases of raw materials and car sales transactions to the affiliated parties such as Indonesia's TAM (Toyota Astra Motor) and Singapore's TMAP (Toyota Motor Asia Pacific) causing TMMIN's profit before taxes was reduce. This has an impact on the company financial performance where managers decide to conduct tax avoidance by measuring the benefits and costs incurred. Managers will conduct tax avoidance only if the benefits are as expected (Gallemore et al, 2014).

\section{Literature Review and Hypothesis Development Tax Planning}

According to Zain (2008) tax planning (tax planning) is a structuring action that is emphasized to the control of each transaction that has potential consequence of tax so that it can make amount of taxes efficient to be transferred to the government. According to Padnyana et. al (2017) tax planning is used in fulfilling its targets for the completion of the tax obligation, based on tax planning methods that are correct, complete and timely, and still follow the tax laws so as to avoid an administrative sanction or criminal sanction.

According to Farida et. al (2014) there are five reasons WP conduct tax planning, which are it is allowed by law, it can maximize the operating profit after taxes, the lack of tax justice, especially in tax levy where tax officers focus only on existing WP without seeking new WP, taxation system that makes taxpayers less comfortable, and the duality of obligation makes WP more likely to make religious charity and donations rather than paying taxes.

One of the tax planning measurements is GAAP ETR. According to Meilinda (2013), the GAAP ETR value is estimated using a one year tax burden amount as a numerator and a one year income before tax as the denominator. The better the ETR value is indicated by the lower the ETR value. The lower the ETR value means the better company's tax planning.

\section{Company's Reputation}

Reputation has different definitions because reputation can be seen from different points of view. However, reputation is often associated with an image of an organization in public (Pebriani, 2015). Hardjana (2008) suggests 3 (three) strategic advantages of a strong company's positive reputation strongly associated with the warmth of relationship and commitment that is in the competition between similar products and similar quality levels, the reputation of the company gives preference to build business relationship, reputation can attract support if the company faces a controversial situation, and in the money market, reputation is a company's value. Company's reputation is measured by using Cll rating issued by Frontier Consulting Group. CII is an award given 
INTERNATIONAL JOURNAL OF ACADEMIC RESEARCH IN BUSINESS AND SOCIAL SCIENCES

Vol. 8, No. 8, August 2018, E-ISSN: 2222-6990 @ 2018 HRMARS

to companies with the best (excellent) reputation or brand image and also the bad (non excellent) reputation in Indonesia.

\section{Financial Performance}

The company's financial performance describes whether or not a company's financial is healthy over a period/ particular period of time. This can be done by comparing two elements in the financial statements called ratio (Christianti, 2014). According to Graham et. al (2014) public company is very important to focus on financial statements rather than private companies because the financial statements are used so as to tax planning action is not wrong in reporting earnings per share of the company. Financial performance may positively influence the willingness to fulfil the tax requirements so that WP must also consider its financial performance. If the income recieved has exceeded PKP (Taxable Income), the taxpayer is required to pay taxes and is required to report the income tax received (Aryobimo, 2012).

Company's financial performance is measured by using ROE ratio. According to Wedha (2017) ROE is a ratio that shows a company's ability to generate net profit by using its own capital and generate net profit available to owners or investors. ROE compares net profit after tax with equity invested by company's shareholders which means that the higher ROE ratio, the higher the value of the company, this is certainly an attraction for investors to invest their capital in the company.

\section{The Influence of Company's Reputation and the Company's Financial Performance towards Tax Planning}

Tax planning has a very important role for every company where the company is trying to apply tax laws correctly and efficient efforts to achieve ideal profit and liquidity (Suandy, 2011, p. 6). Therefore, tax planning can increase the value or reputation of the company because it can be more effective in paying taxes and perceived orderly in paying tax obligations.

Payment of taxes in the company is very influential in the continuity of the company's operations that will reduce the amount of net profit of the company. Tax planning which is carried out to adjust the tax payment to the company's financial performance by looking at proven profitability of the company is one of the factors affecting the company in obeying tax regulations (Slemlord, 1992; Bradley, 1994; and Siahaan, 2005 in Nalendro and Isgiyarta, 2014).

There are many factors influence the tax planning, but, this research indicates in terms of reputation and financial performance of companies to be examined on its influence towards tax planning of public companies in Indonesia. Based on that description, it is formulated the following hypothesis:

$\mathbf{H}_{1}$ : The company's reputation and company's financial performance simultaneously influence toward tax planning

$\mathbf{H}_{\mathbf{2}}$ : The company's reputation negatively influence tax planning.

$\mathbf{H}_{3}$ : The company's financial performance positively influence tax planning

\section{Research Method \\ Study Design}

The population of companies used in this research are companies that are not included in the finance sector during the period of 2012-2016. The reason is because that industry has special characteristics based on PP (Government Regulation) No. 42 of 1985 article 6 about PKP (taxable income), Law no. 36 of 2008 Article 25 paragraph 7 (b) about income tax, and PMK (Regulation of the 
INTERNATIONAL JOURNAL OF ACADEMIC RESEARCH IN BUSINESS AND SOCIAL SCIENCES Vol. 8, No. 8, August 2018, E-ISSN: 2222-6990 @ 2018 HRMARS

Minister of Finance) No. 251/PMK.03/2008 about income on financial services performed by a business entity serving as a lending distributor and/or financing that is not subject to withholding of income tax article 23. This research uses the sample. Sample selection in this research is done by purposive sampling method so that it result in 54 companies that become research sample with amount of 270 observation data during the period of 2012-2016.

The method of analysis used in this study is multiple regression analysis (multiple regression analysis). Using the model as follows:

$Y=\propto+\beta_{1} X_{1}+\beta_{2} X_{2}+e$

Where $X_{1}=$ Company's Reputation; $X_{2}=$ Company's financial performance; $Y=$ Tax Planning; $\propto=$ Constants; $\beta_{1}, \beta_{2}=$ Value of regression coefficient; $e=$ Error terms

\section{Results and Discussion}

\section{Classic Assumption Test}

Classic assumption test which is normality test is done by using statistical test of non parametrik One-Sample Kolmogorov-Smirnov Test. Result of data processing show normal distribution data with significance level $>0.05$. The multicolonierity test is performed with a correlation matrix by looking at the level of the VIF (Variance Inflation Factor) value and the tolerance value. It can be concluded that in the regression model freed from multicolonierity between independent variables. Heteroscedasticity test is done by looking at the scatterplot chart. The result of the heteroscedasticity test shows the spread of points randomly that does not form a certain pattern so that it can be summarized that the model does not happen heteroscedasticity.

\section{Hypothesis testing}

Based testing done with hypothesis testing using multiple regression analysis. Multiple linear analysis is used to obtain regression coefficients which will determine whether the hypothesis made will be accepted or rejected. Based on the regression analysis using SPSS program it is obtained the results that can be seen in Table 1.1.

Table 1.1

Analysis Result of The Influence of Company's Reputation and Company's Financial Performance toward Tax Planning

\begin{tabular}{|c|c|c|c|c|c|c|}
\hline \multirow{2}{*}{\multicolumn{2}{|c|}{ Model }} & \multicolumn{2}{|c|}{$\begin{array}{l}\text { Unstandardized } \\
\text { Coefficients }\end{array}$} & \multirow{2}{*}{$\begin{array}{c}\text { Standardized } \\
\text { Coefficients } \\
\text { Beta }\end{array}$} & \multirow[b]{2}{*}{$l$} & \multirow[b]{2}{*}{ Sig. } \\
\hline & & B & Std. Error & & & \\
\hline \multirow[t]{3}{*}{1} & (Constant) & ,266 & ,007 & & 36,269 &, 000 \\
\hline & Reputation &,- 031 & ,008 &,- 214 & $-4,066$ & ,000 \\
\hline & $\begin{array}{l}\text { Financial } \\
\text { Performance }\end{array}$ & 169 & 019 & , 477 & 9,079 & ,000 \\
\hline
\end{tabular}

a. Dependent Variable: Tax Planning

Source: SPSS Output 
INTERNATIONAL JOURNAL OF ACADEMIC RESEARCH IN BUSINESS AND SOCIAL SCIENCES Vol. 8, No. 8, August 2018, E-ISSN: 2222-6990 @ 2018 HRMARS

Table 1.2

Statistical Test $\mathbf{F}$

\begin{tabular}{|c|c|c|c|c|c|c|}
\hline \multicolumn{7}{|c|}{ ANOVA $^{a}$} \\
\hline \multicolumn{2}{|c|}{ Model } & Sum of Squares & $d f$ & $\begin{array}{l}\text { Mean } \\
\text { Square }\end{array}$ & $\mathrm{F}$ & Sig. \\
\hline \multirow[t]{3}{*}{1} & Regression & ,294 & 2 & ,147 & 48,032 &, $000^{b}$ \\
\hline & Residual & ,818 & 267 & ,003 & & \\
\hline & Total & 1,112 & 269 & & & \\
\hline
\end{tabular}

a. Dependent Variable: Tax Planning

b. Predictors: (Constant), Financial Performance, Reputation

Source: SPSS Output

Based on Table 1.1 and Table 1.2, it is concluded about the hypothesis testing among variables as follows:

The influence of company's reputation and company's financial performance simultaneously toward tax planning

The test results indicate that the first hypothesis testing is that the company's reputation simultaneously influence tax planning if there is at least one $\beta i(i=1,2) \neq 0$. Criteria determination is based on regression coefficient value $\beta i \neq 0, i=1,2$ which are $-0,031$ and 0,169 . Based on these criteria, the result of this study receives $\mathrm{H}_{\mathrm{a} 1}$ (alternative hypothesis) or reject $\mathrm{H}_{01}$ (null hypothesis). $\mathrm{F}$ test result shows a value of 48,032 with a probability of 0,000 , smaller than the value of $0,05(5 \%)$. This shows that the company's reputation and financial performance simultaneously influence tax planning.

\section{The influence of company's reputation toward tax planning}

In hypothesis testing, it is stated that company's reputation influence tax planning if $\beta 1 \neq 0$. Criteria determination is based on the value of regression coefficient $\beta_{1} \neq 0$, which is $-0,031$. Based on these terms, the result of this research receives $\mathrm{H}_{\mathrm{a} 2}$ (alternative hypothesis) or reject $\mathrm{H}_{02}$ (null hypothesis). Result of $t$ test shows value equal to $-4,066$ with a significance level of 0,000 smaller than the 0,05 significance level (5\%). This shows that the company's reputation is proven to negatively influence tax planning. The result of this research is in accordance with the statement of Gallemore et. al (2014) that company's reputation is positioned as an important factor limiting the activity of tax planning, especially aggressive tax planning.

\section{The influence of the company's financial performance toward tax planning}

In hypothesis testing, it is stated that company's financial performance influence tax planning if $\beta_{2} \neq 0$. Criteria determination is based on the regression coefficient value $\beta_{2} \neq 0$, which is 0,169 . Based on these criteria, the result of this research receives $\mathrm{H}_{a 3}$ (alternative hypothesis) or reject $\mathrm{H}_{03}$ (null hypothesis). The result of $t$ test shows a value of 9,079 with significance level 0,000 smaller from significance level 0.05 (5\%). This shows that the company's financial performance is proven to positively influence tax planning.

Anggraeni, et. al (2017) who explained that tax planning significantly influence company's equity. Financial performance may positively influence the willingness to fulfill the tax requirements 
INTERNATIONAL JOURNAL OF ACADEMIC RESEARCH IN BUSINESS AND SOCIAL SCIENCES

Vol. 8, No. 8, August 2018, E-ISSN: 2222-6990 C 2018 HRMARS

so that WP must also consider their financial condition. If the income received exceeds the taxable income (PKP), the taxpayer is required to pay taxes and is required to report the income tax received (Aryobimo, 2012).

\section{Determination Coefficient Test (Adjusted $\mathbf{R}^{2}$ )}

In a multiple linear regression tests it is also analyzed the value of determination coefficient ( $R$ ${ }^{2}$ ). Table 1.3 shows the value of $R$ square for the effect of variables in this study.

Tabel 1.3

R Square Value

\begin{tabular}{|l|r|r|r|r|}
\hline Model & $\mathrm{R}$ & R Square & Adjusted R Square & \multicolumn{2}{|c|}{$\begin{array}{c}\text { Std. Error of the } \\
\text { Estimate }\end{array}$} \\
\hline 1 &, $514^{\mathrm{a}}$ &, 265 &, 259 &, 05535 \\
\hline
\end{tabular}

a. Predictors: (Constant), Financial Performance, Reputation

b. Dependent Variable: Tax Planning Source: SPSS Output

Based on table 1.3 , the test result shows the coefficient of $\mathrm{R}^{2}$ of 0,265 or $26,5 \%$. So it can be said that $26,5 \%$ of tax planning of public company in Indonesia is caused by company's reputation and company's financial performance, while $73,5 \%$ of tax planning is caused by other factors which are not examined in this study.

\section{Separate Testing of Excellent and Non Excellent Company's Reputation}

Table 1.4

Descriptive Statistics of Excellent and Non Excellent Company's Reputation

\begin{tabular}{|c|c|c|c|}
\hline \multicolumn{2}{|c|}{ Reputation } & Tax Planning & $\begin{array}{c}\text { Financial } \\
\text { Performance }\end{array}$ \\
\hline \multirow{5}{*}{$\begin{array}{l}\text { Non } \\
\text { Excellent }\end{array}$} & $\mathrm{N}$ & 70 & 70 \\
\hline & Minimum & ,12 & ,00 \\
\hline & Maximum &, 43 & ,46 \\
\hline & Mean & 2947 & 1703 \\
\hline & $\begin{array}{l}\text { Std. } \\
\text { Deviation }\end{array}$ & ,06412 & 12256 \\
\hline \multirow[t]{5}{*}{ Excellent } & $\mathrm{N}$ & 200 & 200 \\
\hline & Minimum & ,14 & ,00 \\
\hline & Maximum & ,50 & 1,36 \\
\hline & Mean & ,2663 & , 1875 \\
\hline & $\begin{array}{l}\text { Std. } \\
\text { Deviation }\end{array}$ & ,06288 & 19858 \\
\hline
\end{tabular}

Source: SPSS Output

Based on Table 1.4, it can be seen the highest value of company's financial performance and the highest average score is found in the group of excellent companies which is 0,1875 or $18,75 \%$ 
INTERNATIONAL JOURNAL OF ACADEMIC RESEARCH IN BUSINESS AND SOCIAL SCIENCES

Vol. 8, No. 8, August 2018, E-ISSN: 2222-6990 @ 2018 HRMARS

compared to the average value of the group of non-excellent companies, which is 0,1703 or $17,03 \%$. Tax planning at non excellent company has an average value of 0,2947 or $29,47 \%$ where the value of tax planning is higher than the group of excellent companies, which is 0,2663 or $26,63 \%$.

\section{Simple regression analysis method}

A simple regression is used to predict (forecast) how far the independent variable $(X)$ affects the dependent variable $(Y)$.

Table 1.5

Analysis Results of The Influence Between The Company's Financial Performance and Tax Planning on Companies that have Excellent Reputation

\begin{tabular}{|c|c|c|c|c|c|c|}
\hline \multicolumn{7}{|c|}{ Coefficients $^{\mathrm{a}, \mathrm{b}}$} \\
\hline & & \multicolumn{2}{|c|}{$\begin{array}{l}\text { Unstandardized } \\
\text { Coefficients }\end{array}$} & $\begin{array}{c}\text { Standardized } \\
\text { Coefficients }\end{array}$ & \multirow[b]{2}{*}{$\mathrm{t}$} & \multirow[b]{2}{*}{ Sig. } \\
\hline \multicolumn{2}{|c|}{ Model } & B & Std. Error & Beta & & \\
\hline \multirow[t]{2}{*}{1} & (Constant) & ,236 & ,005 & & $\begin{array}{r}44,58 \\
4\end{array}$ & ,000 \\
\hline & $\begin{array}{l}\text { Financial } \\
\text { Performance }\end{array}$ & 160 & 019 & ,504 & 8,213 & ,000 \\
\hline
\end{tabular}

Dependent Variable: Tax Planning

Selecting only cases for which Reputation $=1,00$

Source: SPSS Output

Table 1.6

Analysis Results of The Influence Between The Company's Financial Performance and Tax Planning on Companies that have Non-Excellent Reputation

\begin{tabular}{|c|c|c|c|c|c|c|}
\hline \multicolumn{7}{|c|}{ Coefficients $^{\mathrm{a}, \mathrm{b}}$} \\
\hline & & \multicolumn{2}{|c|}{$\begin{array}{l}\text { Unstandardized } \\
\text { Coefficients }\end{array}$} & $\begin{array}{l}\text { Standardized } \\
\text { Coefficients }\end{array}$ & \multirow[b]{2}{*}{$\mathrm{t}$} & \multirow[b]{2}{*}{ Sig. } \\
\hline \multicolumn{2}{|c|}{ Model } & B & Std. Error & Beta & & \\
\hline \multirow[t]{2}{*}{1} & (Constant) & ,254 & 012 & & $\begin{array}{r}21,47 \\
7\end{array}$ & $\begin{array}{r}00 \\
0\end{array}$ \\
\hline & $\begin{array}{l}\text { Financial } \\
\text { Performance }\end{array}$ & 237 & ,057 & ,452 & 4,182 & $\begin{array}{r}, 00 \\
0\end{array}$ \\
\hline
\end{tabular}

Dependent Variable: Tax Planning

Source: SPSS Output

Selecting only cases for which Reputation $=, 00$

Based on table 1.5 it is obtained the result of the regression equation between the company's financial performance $(\mathrm{X})$ and tax planning on company that has excellent reputation $(\mathrm{Y})$ as follows: $Y=0,236+0,160 X_{2}+e$

From result of regression analysis between company's financial performance $(X)$ and tax planning at company with non-excellent reputation $(Y)$ in table 1.6, we find the following equation: $Y=0,254+0,237 X_{2}+e$ 
INTERNATIONAL JOURNAL OF ACADEMIC RESEARCH IN BUSINESS AND SOCIAL SCIENCES

Vol. 8, No. 8, August 2018, E-ISSN: 2222-6990 @ 2018 HRMARS

Analysis of the influence between the company's financial performance and tax planning on companies that have excellent and non-excellent reputation

The financial performance of the company shows $t$ value of 8,213 with a significance level of 0.000 smaller than the significance level of $0,05(5 \%)$. This shows that the company's financial performance has an influence toward the tax planning of public companies that have excellent reputation. The same thing is happened for company with non-excellent reputation where the company's financial performance has a t value of 4,182 with a significance level of 0.000 smaller than the significance level of 0.05 (5\%). This shows that the company's financial performance has an influence toward tax planning of public company that has a non-excellent reputation.

These results indicate that both company with excellent and non-excellent reputation will affect the tax planning action where it is proven that the company's reputation lowers the tax planning action.

\section{Determination Coefficient Test}

Table 1.7

R Square Value of Excellent Reputation

\begin{tabular}{|c|c|c|c|c|}
\hline \multirow[b]{2}{*}{ Model } & $R$ & \multirow[b]{2}{*}{$\begin{array}{c}\text { R } \\
\text { Square }\end{array}$} & \multirow[b]{2}{*}{$\begin{array}{l}\text { Adjusted R } \\
\text { Square }\end{array}$} & \multirow[b]{2}{*}{$\begin{array}{c}\text { Std. Error of the } \\
\text { Estimate }\end{array}$} \\
\hline & $\begin{array}{c}\text { Reputation }=1,00 \\
\text { (Selected) }\end{array}$ & & & \\
\hline 1 &, $504^{a}$ & ,254 & ,250 & ,05445 \\
\hline
\end{tabular}

Predictors: (Constant), Financial Performance

Unless noted otherwise, statistics are based only on cases for which Reputation $=1,00$.

Dependent Variable: Tax Planning

Source: SPSS Output

Tabel 1.8

R Square Value of Non-Excellent Reputation

\begin{tabular}{|c|c|c|c|c|}
\hline \multirow[b]{2}{*}{ Model } & $R$ & \multirow[b]{2}{*}{$\begin{array}{c}\text { R } \\
\text { Square }\end{array}$} & \multirow[b]{2}{*}{$\begin{array}{l}\text { Adjusted R } \\
\text { Square }\end{array}$} & \multirow[b]{2}{*}{$\begin{array}{c}\text { Std. Error of the } \\
\text { Estimate }\end{array}$} \\
\hline & $\begin{array}{l}\text { Reputation }=, 00 \\
\text { (Selected) }\end{array}$ & & & \\
\hline 1 & $452^{a}$ & 205 & 193 & 05761 \\
\hline
\end{tabular}

Predictors: (Constant), Financial Performance

Unless noted otherwise, statistics are based only on cases for which Reputation $=00$.

Dependent Variable: Tax Planning

Source: SPSS Output

Determination coefficient test result in company that has excellent reputation can be seen at table 1.7, it is seen the value of the determination coefficient $\left(R^{2}\right)$ is 0,254 . This shows that tax planning can be caused by the public company's financial performance that has excellent reputation of $25,4 \%$, while $74,6 \%$ is caused by other factors.

In Table 1.8 it shows that the determination coefficient $\left(R^{2}\right)$ is 0,205 in company with nonexcellent reputation. This means that $20,5 \%$ of the amount of tax planning can be caused by the 
INTERNATIONAL JOURNAL OF ACADEMIC RESEARCH IN BUSINESS AND SOCIAL SCIENCES

Vol. 8, No. 8, August 2018, E-ISSN: 2222-6990 @ 2018 HRMARS

public company's financial performance that has a non-excellent reputation, while $79,5 \%$ is caused by other factors.

\section{Conclusion}

The results of this study indicate evidence that reputation (both companies that have excellent and non-excellent reputation) and financial performance of companies may have an effect tax planning of public companies in Indonesia. In accordance with the results of this study has been analyzed that not only financial information (financial report) but also non-financial information (reputation index) which can help investors and directors of the company to consider making decisions related to tax planning analysis applied by public companies. This information is very useful both in order to tax planning right on target and continue to maintain the credibility and going concern of the companies.

\section{Limitations}

a. This research only examines public companies that are included in the list of Frontier Consulting Group for the period of 2012-2016. Frontier Consulting Group is an institution that conducts an assessment of the company's reputation using Cll which cause the results of this research maybe have limited generalize to public companies in Indonesia in general.

b. This research also uses ROE indicator in assessing company's financial performance level, so that the result of this research cannot be used as a reference in measuring level of financial performance of public company by using other proxy.

c. The indicator to measure tax planning using GAAP ETR, therefore this research is less relevant to compare with others research that used other variables.

\section{Acknowledgments}

Thanks to my supervisors, Mrs. Yossi Diantimala and Mrs. Zuraida for all their guidance.

\section{References}

Anggraeni, D., Handayani, D., \& Ananto, R.P. (2017). Analisis Pengaruh Tax Planning terhadap Ekuitas Perusahaan. Journal of Applied Accounting and Taxation, 8 (2), 107-113.

Aryobimo, P.T., \& Cahyonowati, N. (2012). Pengaruh Persepsi Wajib Pajak tentang Kualitas Pelayanan Fiskus terhadap Kepatuhan Wajib Pajak dengan Kondisi Keuangan Wajib Pajak dan Preferensi Risiko sebagai Variabel Moderating (Studi Empiris terhadap Wajib Pajak Orang Pribadi di Kota Semarang). Diponegoro Journal of Accounting, 1 (2), 1-12.

Cook, K.A., Moser, W.J., \& Omer, T.C. (2017). Tax Avoidance and Ex Ante Cost of Capital. Journal of Business Finance \& Accounting, 44 (7-8), 1109-1136

Christianti, A. (2014). Pengaruh Kondisi Keuangan terhadap Manipulasi Aktivitas Riil. E-Journal Ekonomi Akuntansi, 1-15.

Dugaan Transfer Pricing Toyota. (2017, 3 Maret). Kompasiana. Retrieved from https://www.kompasiana.com/kompaskampus/58b8c532b69373f804571eda/dugaantransfer-pricing-toyota

Farida, N., Ludigdo, U., \& Irianto, G. (2014). Fenomenologi Praktik Tax Planning Pada Wajib Pajak Badan. El-Muhasaba, 5 (1).

Gallemore, J., Maydew, E.L., \& Thornock, J.R. (2014). The Reputational Cost of Tax Avoidance. Contemporary Accounting Research, 31 (4), 1103-1133. 
INTERNATIONAL JOURNAL OF ACADEMIC RESEARCH IN BUSINESS AND SOCIAL SCIENCES

Vol. 8, No. 8, August 2018, E-ISSN: 2222-6990 @ 2018 HRMARS

Graham, J.R., Hanlon, M., Shevlin, T., \& Shroff, N. (2014). Incentives for Tax Planning and Avoidance: Evidence from The Field. The Accounting Review, 89 (3), 991-1023.

Hardjana, A.A. (2008). Komunikasi dalam Manajemen Reputasi Korporasi. Jurnal Komunikasi. 5 (1), $1-24$.

Meilinda, M., \& Cahyonowati, N. (2013). Pengaruh Corporate Governance terhadap Manajemen Pajak. Diponegoro Journal of Accounting, 2 (3), 2337-3806.

Mustami, A. A. (2014, 13 Juni). Coca-Cola Diduga Akali Setoran Pajak. Kompas. Retrieved from https://ekonomi.kompas.com/read/2014/06/13/1135319/CocaCola.Diduga.Akali.Setoran.Pajak

Nalendro, T.I., \& Isgiyarta. (2014). Faktor-Faktor yang Mempengaruhi Kepatuhan Membayar Pajak Wajib Pajak Orang Pribadi yang Berwirausaha dengan Lingkungan Sebagai Variabel Moderasi (Studi Empiris Di KPP Pratama Kudus). Diponegoro Journal of Accounting, 3 (3), 1-15.

Padnyana, I.B.G.P., \& Noviari, N. (2017). Pengaruh Perencanaan Pajak terhadap Nilai Perusahaan dengan Transparansi Perusahaan Sebagai Variabel Pemoderasi. Jurnal Akuntansi Universitas Udayana, 8 (2), 1398-1425.

Pebriani, A. \& Hermawan, A.A. (2015). Reputasi Perusahaan, Kepemilikan Keluarga, Hubungan Politik, dan Borrowing Capacity. Simposium Nasional Akuntansi, 18, September 16-17, 2015.

Direktorat Jenderal Pajak. (2016, 30 November). Penerimaan Pajak Non PPh Migas 2016 Tumbuh 29,15\%. Retrieved from http://www.pajak.go.id/content/article/penerimaan-pajak-nonpph-migas-2016-tumbuh-2915

Rahman, A. (2012). Keuangan Teori dan Aplikasi. Tax Planning (Perencanaan Pajak), Perlukah? Kajian Praktis Menuju Administrasi Pajak yang Efisien. Retrieved from http//:www.itokindo.org

Republik Indonesia. (1985). Peraturan Pemerintah No. 42 tahun 1985 pasal 6 tentang Penghasilan Kena Pajak

Republik Indonesia. (2008). Undang-Undang No.36 tahun 2008 pasal 25 ayat 7 (b) tentang pajak penghasilan

Republik Indonesia. (2008). Peraturan Menteri Keuangan No. 251/PMK.03/2008 tentang penghasilan atas jasa keuangan yang dilakukan oleh badan usaha yang berfungsi sebagai penyalur pinjaman dan/atau pembiayaan yang tidak dilakukan pemotongan pajak penghasilan pasal 23.

Direktorat Jenderal Pajak. (2017, 3 November). Reformasi Perpajakan. Retrieved from http://www.pajak.go.id/reformasi-pajak

Suandy, E. (2011). Perencanaan Pajak. Fifth edition. Salemba Empat.

Wedha, M.A.S. (2017). Pengaruh Tax Planning terhadap Return on Equity (ROE) pada Sektor Makanan dan Minuman yang Terdaftar di BEI Tahun 2013-2015. Jurnal KRISNA (Kumpulan Riset Akuntansi), 9 (1), 30-35.

Zain, M. (2008). Manajemen Perpajakan. Jakarta: Salemba Empat 